\title{
Identifikasi Keragaman Genetik Gen Reseptor Hormon Pertumbuhan (GHR I Alu I) pada Sapi Bali
}

\author{
Identification of Genetic Diversity of Growth Hormone Receptor (GHR $\mid A l u$ I) Gene in Bali Cattle
}

\author{
Zulkharnaim ${ }^{\mathrm{a}}{ }^{*}$ Jakariab $^{\mathrm{b}}$ \& R. R. Noor ${ }^{\mathrm{b}}$ \\ aProgram Studi Ilmu Produksi dan Teknologi Peternakan, Sekolah Pascasarjana, Institut Pertanian Bogor \\ ${ }^{b}$ Departemen Ilmu Produksi dan Teknologi Peternakan, Fakultas Peternakan, Institut Pertanian Bogor \\ Jln. Agatis, Kampus IPB Darmaga Bogor 16680 \\ (Diterima 21-04-2010; disetujui 07-06-2010)
}

\begin{abstract}
Growth hormone receptor (GHR) is one factor affecting animal growth. GHR is required by growth hormone $(\mathrm{GH})$ to carry out its effects on target tissues. The objective of the study was to estimate genetic diversity of the GHR |AluI gene in bali, limousin, simmental and pesisir cattle. Genotyping was performed on 248 animals, including 162 bali, 21 limousin, 17 simmental and 48 pesisir. Single nucleotide polymorphisms (SNP) had been found in exon 10, coding for the cytoplasmic domain of GHR, which was located at position $81 \mathrm{bp}(\mathrm{A} / \mathrm{G})$ induced amino acid substitutions Ser/Gly. Genotype frequencies of bali cattle AA (0.988), GG (0.006) and AG (0.006) were evidenced for the GHR AluI monomorphism, but mostly different from limousin GG (0.667), AA (0.238) and AG (0.095), simmental AG (0.529), GG (0.471) and AA (0.000), pesisir AA (0.604), GG (0.375) and AG (0.021) were the evidence of polymorphism. Homozigosity (monomorphism) in bali cattle might be affected by adaptability in extreme environmental conditions such as poor nutrition and improper management practices. It also could be affected by natural selection and phenotype plasticity phenomena.
\end{abstract}

Key words: Bali cattle, GHRIAlu I, genetic diversity, PCR-RFLP, sequencing

\section{PENDAHULUAN}

Ternak sapi memberikan kontribusi cukup besar dalam penyediaan daging nasional. Berdasarkan produksi daging nasional 2008, kontribusi daging sapi mencapai lebih dari 352 ribu ton, yaitu sekitar 16,2\% dari total produksi daging nasional dari beberapa komoditas ternak, dan menempati peringkat kedua setelah produksi daging unggas (Direktorat Jenderal Peternakan, 2009). Perannya yang sedemikian penting menjadi alasan mengapa produktivitas dan populasi sapi di Indonesia mendapat perhatian cukup besar dari pemerintah.

Sapi bali merupakan salah satu dari empat bangsa sapi lokal utama (aceh, pesisir, madura, dan bali) di Indonesia. Keunggulan sapi bali antara lain memiliki tingkat fertilitas tinggi $(80 \%-82 \%)$, daya adaptasi yang baik terhadap lingkungan baru, produksi karkas yang tinggi, heterosis positif tinggi pada persilangan (Noor et al., 2001), dan memiliki daging berkualitas baik dengan kadar lemak rendah (Bugiwati, 2007). Beberapa sifat produksi dan reproduksi tersebut merupakan sifat ekonomis dan biologis penting yang dapat digunakan

*Korespondensi:

e-mail: almaupa_anim@yahoo.co.id sebagai indikator seleksi (Handiwirawan \& Subandriyo, 2004).

Sapi bali memiliki kemampuan adaptasi yang tinggi terhadap lingkungan yang marjinal, hal tersebut berpengaruh terhadap pertumbuhan yang menunjukkan keragaman pada kondisi lingkungan yang berbeda. Salah satu faktor yang mempunyai peranan di dalam pertumbuhan suatu individu adalah gen hormon pertumbuhan (growth hormone/GH). Gen GH dibutuhkan untuk pertumbuhan jaringan, metabolisme lemak, pengaturan reproduksi, laktasi, pertumbuhan tubuh normal (Beauchemin et al., 2006) dan sifat pertumbuhan pada sapi pedaging (Hale et al., 2000). Faktor lain yang mempengaruhi pertumbuhan dari individu adalah gen reseptor hormon pertumbuhan (growth hormone receptor/GHR). Zhou \& Jiang (2005) menyatakan bahwa pada tingkatan jaringan, aksi biologis dari gen GH dimediasi oleh gen GHR. Berdasarkan fungsi mediasi yang dimiliki oleh gen GHR maka keragaman pertumbuhan ternak sapi dapat juga diidentifikasi dari keragamannya.

Gen bovine growth hormone receptor (bGHR) disandikan sebagai gen tunggal dan terletak pada kromosom 20 (Lin et al., 2009). Single nucleotide polymorphism (SNP) ditemukan pada ekson 10 pada posisi $257 \mathrm{pb}(\mathrm{A} / \mathrm{G})$ yang mengubah susunan asam amino serina menjadi 
glisina (Ge et al., 2000). Hubungan antara keragaman gen GHR|AluI dan sifat pertumbuhan sapi telah dilakukan pada sifat in vivo dan karakteristik daging sapi Piedmontese (Di Stasio et al., 2005), lemak karkas pada sapi Bos taurus (Tatsuda et al., 2008), lemak intra muskular (Han et al., 2009) dan komposisi otot (lemak intramuskular, protein dan kadar air) (Reardon et al., 2010).

Tujuan penelitian ini adalah untuk mempelajari keragaman gen reseptor hormon pertumbuhan (GHR)|AluI (lokus AluI) pada sapi bali. Informasi ini penting sebagai salah satu informasi dasar dalam rangka melengkapi kerangka kerja genetika molekuler dalam upaya perbaikan mutu genetik, strategi pengembangan dan penentuan kebijakan pengembangan sapi bali agar pemanfaatannya bisa berjalan secara berkelanjutan.

\section{MATERI DAN METODE}

\section{Sampel DNA}

Isolasi DNA dilakukan dari sampel darah menggunakan genomic DNA mini kit Geneaid. Sampel DNA yang digunakan dalam penelitian ini sebanyak 248 sampel. Sampel DNA tersebut diisolasi dari sampel darah dengan distribusi 162 sampel sapi bali (10 dari UP3 Bali dan 152 dari BIBD Bali). Sebagai pembanding, digunakan 21 sampel sapi limousin (BIB Singosari Malang), 17 sampel sapi simmental (BIB Singosari Malang), dan 48 sampel sapi pesisir (Kabupaten Pesisir Selatan).

\section{Amplifikasi Fragmen Gen GHR $\mid A l u \mathbf{I}$}

Amplifikasi gen GHRIAluI dengan mesin thermal cycler dilakukan menggunakan metode PCR. Primer yang digunakan untuk mengamplifikasi ruas gen GHR ekson 10 mengikuti Andreas (2010), dengan runutan primer forward 5'-CGCTTACTTCTGCGAGGTAGACGC3' dan primer reverse 5'-GTCTGTGCTCACATAGCCAC3'. Panjang fragmen hasil ampilifikasi sepanjang $298 \mathrm{pb}$.

Komponen pereaksi yang digunakan untuk amplifikasi ruas gen GHR|AluI adalah $2 \mu \mathrm{l}$ sampel DNA, masing-masing primer 0,5 pmol, campuran dNTP 0,2 $\mathrm{mM}, \mathrm{MgCl}_{2} 2 \mathrm{mM}$, taq polymerase (real taq) 0,1 unit dan bufernya dalam larutan total $25 \mu$ l. Proses amplifikasi dilakukan pada mesin thermal cycler (Eppendorf Type 5332) dengan kondisi mesin sebagai berikut: denaturasi awal pada suhu $94{ }^{\circ} \mathrm{C}$ selama 5 menit, 35 siklus terdiri atas denaturasi pada suhu $94{ }^{\circ} \mathrm{C}$ selama 45 detik, penempelan primer pada suhu $60{ }^{\circ} \mathrm{C}$ selama 1 menit dan pemanjangan DNA baru pada suhu $72{ }^{\circ} \mathrm{C}$ selama 1 menit 30 detik, dan pemanjangan akhir pada suhu $72{ }^{\circ} \mathrm{C}$ selama 5 menit.

\section{Identifikasi Keragaman Gen GHR $\mid A l u \mathbf{I}$}

Identifikasi keragaman gen GHRIAluI dilakukan menggunakan metode polymerase chain reaction-restriction fragment length polymorphism (PCR-RFLP) menggunakan enzim pemotong AluI (lokus GHR AluI) dengan situs pemotongan AGICT. Produk PCR-RFLP divisualisasikan pada gel agarosa $2 \%(0,6 \mathrm{~g}$ agarosa/30 $\mathrm{ml} \mathrm{0,5x} \mathrm{TBE),}$ dilanjutkan dengan pewarnaan etidium bromida dan divisualisasikan pada UV transilluminator.

\section{Analisis Data}

Frekuensi alel dihitung menggunakan rumus Nei \& Kumar (2000), dengan $x_{i}$ adalah frekuensi alel ke-i, $N_{i i}$ adalah jumlah individu bergenotipe $\mathrm{A}_{\mathrm{i}} \mathrm{A}_{\mathrm{i}}, N_{i j}$ adalah jumlah individu bergenotipe $\mathrm{A}_{i} \mathrm{~A}_{j}$ dan $N$ adalah jumlah total sampel.

$$
x_{i}=\frac{\left(2 N_{i i}+\sum_{j \neq i} N_{i j}\right)}{2 N}
$$

Keseimbangan Hardy-Weinberg (H-W) diuji dengan uji khi-kuadrat (Kaps \& Lamberson, 2004), dengan $\chi^{2}$ adalah uji khi-kuadrat, obs adalah jumlah pengamatan genotipe ke-i, dan exp adalah jumlah harapan genotipe ke-i.

$$
\chi^{2}=\sum \frac{(o b s-\exp )^{2}}{\exp }
$$

Heterozigositas pengamatan $\left(H_{0}\right)$ dihitung menggunakan rumus Weir (1996), dengan $H_{0}$ adalah frekuensi heterozigositas pengamatan, $N_{1 i j}$ adalah jumlah individu heterozigositas pada lokus ke-1 dan $N$ adalah jumlah individu yang dianalisa.

$$
H_{o}=\sum_{i \neq j} \frac{N_{1 i j}}{N}
$$

Heterozigositas harapan $\left(H_{e}\right)$ dan ragam heterozigositas harapan dihitung menggunakan rumus Weir (1996), dengan $H_{e}$ adalah heterozigositas harapan, $P_{1 i}$ adalah frekuensi alel ke-i pada lokus 1 dan $n$ adalah jumlah alel pada lokus ke-1.

$$
H_{e}=1-\sum_{1=1}^{n} p_{1 i}^{2}
$$

$\left(V_{s l}\left(H_{e}\right)\right)=$ ragam heterozigositas harapan dan $x_{i}$ adalah frekuensi gen ke-1

$$
V_{s 1}\left(H_{e}\right)=\frac{2}{2_{n}(2 n-1)}\left\{2\left(2_{n}-2\right)\left(\sum x_{i}^{3}-\left(\sum x_{i}^{2}\right)^{2}\right)+\sum x_{i}{ }^{2}-\left(\sum x_{i}{ }^{2}\right)^{2}\right\}
$$

Ragam (SE) heterosigositas harapan diperoleh dari $=$

$$
\sqrt{V_{s 1}}\left(H_{e}\right)
$$

Tingkat informatif suatu alel dihitung menggunakan rumus polymorphic informative content (PIC) (Botstein et al., 1980), dengan $p_{i}$ adalah frekuensi alel ke-i dan $n$ adalah jumlah alel per perinci (marker).

$$
P I C=1-\sum_{i=1}^{n} p_{i}{ }^{2}-\sum_{i=1}^{n-1} \sum_{j=i+1}^{n} 2 p_{i}{ }^{2} p_{j}{ }^{2}
$$

Hasil sekuens fragmen gen GHR|AluI sapi bali, limousin, simmental, dan pesisir dianalisa kesamaannya (homology) dengan sekuen yang terdapat di GenBank menggunakan perangkat lunak (software) komputer program basic local alignment search tool (BLAST) (McGinnis \& Madden, 2004) [www.ncbi.nhl.nih.gov./ BLAST] yang bertujuan untuk memastikan bahwa sekuen yang dianalisa adalah gen GHR dan untuk mengetahui titik mutasi gen GHR | AluI. 


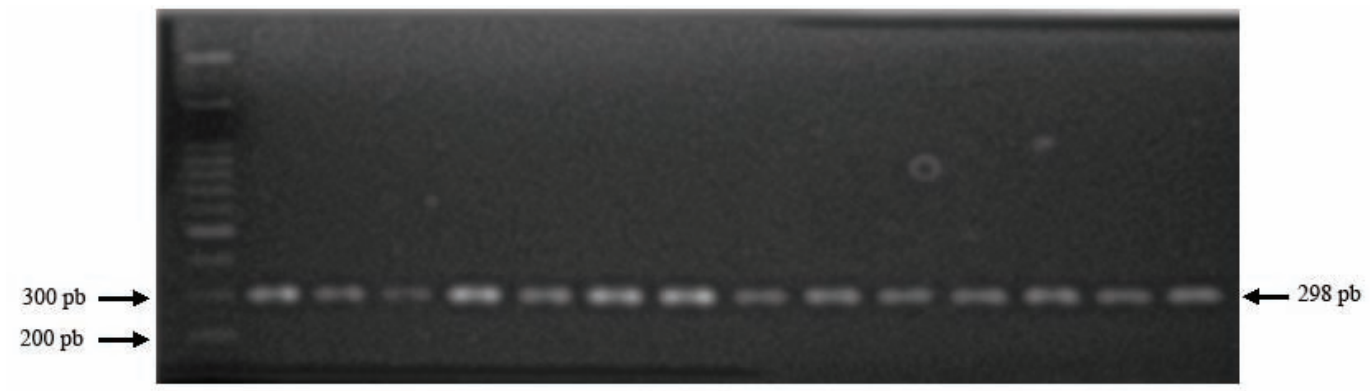

Gambar 1. Produk PCR gen GHR I AluI (298 pb) pada sapi bali

Pohon kekerabatan (phylogenetic trees) dibuat berdasarkan frekuensi genotipe gen GHR I AluI menggunakan software komputer program MEGA 4 (molecular evulotionary genetic analysis) dengan metode UPGMA (unweighted pair-group method with arithmetic mean) (Nei \& Kumar, 2000).

\section{HASIL DAN PEMBAHASAN}

\section{Analisis PCR-RFLP Gen GHR $\mid A l u I$}

Amplifikasi fragmen gen GHR|AluI yang dilakukan pada sapi bali, limousin, simmental, dan pesisir menunjukkan posisi gen GHR pada ekson 10 untuk fragmen gen GHRIAluI dengan produk PCR sepanjang
$298 \mathrm{pb}$ (Gambar 1). Hasil pemotongan fragmen gen GHR $\mid A l u$ I pada sapi bali, limousin, simmental, dan pesisir menghasilkan tiga genotipe, yaitu genotipe AA yang terpotong pada $167 \mathrm{pb}, 81 \mathrm{pb}$ dan $50 \mathrm{pb}$, genotipe GG pada $167 \mathrm{pb}$ dan $131 \mathrm{pb}$, sedangkan genotipe AG pada 167 pb, 131 pb, 81 pb dan 50 pb (Gambar 2 dan Gambar 3). Mutasi pada gen GHR I AluI mengubah basa adenin (A) menjadi guanin (G) pada posisi 81 pb yang menyebabkan perubahan asam amino serina (AGC) menjadi glisina (GGC).

\section{Keragaman Gen GHR $\mid A l u \mathrm{I}$}

Perbedaan frekuensi genotipe gen GHR I AluI (Tabel 1) antara sapi bali, limousin, simmental, dan pesisir,

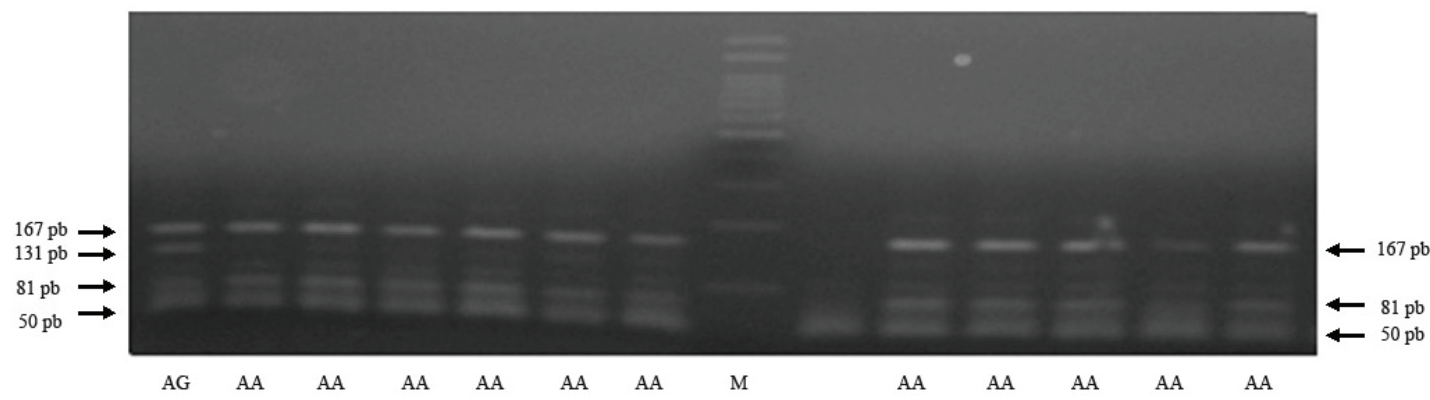

Gambar 2. Genotipe hasil pemotongan produk PCR gen GHR I AluI sapi bali

$\mathrm{M}$ (marker)= ladder $100 \mathrm{pb}$; AA= individu homozigot $(167 \mathrm{pb}, 81 \mathrm{pb}$ dan $50 \mathrm{pb})$; $\mathrm{AG}=$ individu homozigot $(167 \mathrm{pb}, 131 \mathrm{pb}$, $81 \mathrm{pb}$, dan $50 \mathrm{pb})$

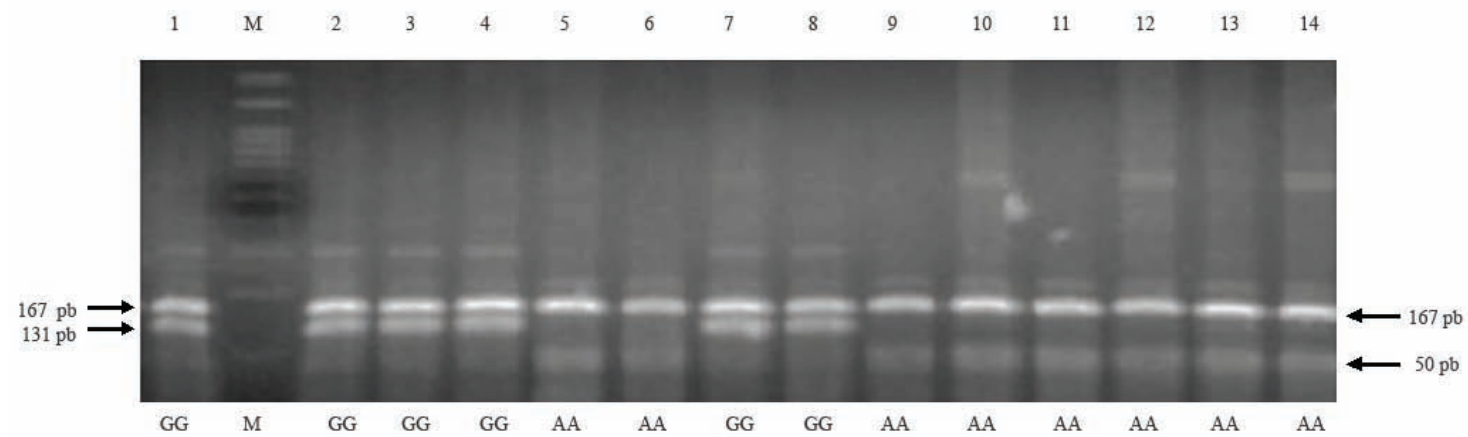

Gambar 3. Genotipe hasil pemotongan produk PCR gen GHR I AluI pada sapi bali

$\mathrm{M}$ (marker)= ladder $100 \mathrm{pb} ; \mathrm{AA}=$ individu homozigot $(167 \mathrm{pb}, 81 \mathrm{pb}$, dan $50 \mathrm{pb})$; GG= individu homozigot (167 pb dan $131 \mathrm{pb} ; 1,2,12,13,14=$ sapi limousin; 3,4,5,6= sapi simmental; 7,8,9,10,11= sapi pesisir. 
Tabel 1. Frekuensi genotipe dan alel gen GHR I AluI pada sapi bali

\begin{tabular}{|c|c|c|c|c|c|c|}
\hline \multirow{2}{*}{ Sapi } & \multirow{2}{*}{$\mathrm{n}$} & \multicolumn{3}{|c|}{ Genotipe } & \multicolumn{2}{|c|}{ Alel } \\
\hline & & AA & AG & GG & A & G \\
\hline Bali & 162 & $0,988^{* *}$ & $0,006^{* *}$ & $0,006^{* *}$ & 0,991 & 0,009 \\
\hline Limousin & 21 & $0,238^{* *}$ & $0,095^{* *}$ & $0,667^{* *}$ & 0,286 & 0,714 \\
\hline Simmental & 17 & $0,000^{\text {ns }}$ & $0,529^{\text {ns }}$ & $0,471^{\text {ns }}$ & 0,265 & 0,735 \\
\hline Pesisir & 48 & $0,604^{* *}$ & $0,021^{* *}$ & $0,375^{* *}$ & 0,615 & 0,385 \\
\hline
\end{tabular}

Keterangan: $\mathrm{n}=$ jumlah individu. $\left.{ }^{* *}\right)$ berbeda sangat nyata, $\mathrm{ns}$ tidak berbeda nyata $(\mathrm{P}<0,05)$.

disebabkan oleh perbedaan bangsa sapi. Ekspresi genetik gen $\mathrm{GHR} \mid A l u \mathrm{I}$ tergantung pada bangsa ternak, frekuensi genotipe AA, AG dan GG pada sapi bali sebesar 0,988; 0,006; dan 0,006, hal ini disebabkan sapi bali termasuk ke dalam bangsa Bos javanicus. Frekuensi genotipe AA, AG dan GG pada sapi limousin sebesar 0,238; 0,095; dan 0,667, dan frekuensi genotipe AA, AG dan GG pada sapi simmental sebesar 0,000; 0,529; dan 0,471, kedua sapi tersebut termasuk ke dalam bangsa Bos taurus. Frekuensi genotipe AA, AG dan GG pada sapi pesisir sebagai sapi lokal selain sapi bali sebesar 0,604; 0,021; dan 0,375.

Keragaman frekuensi alel dan genotipe gen GHRI AluI (Tabel 1) pada sapi bali ditandai dengan frekuensi alel A dan genotipe AA yang tinggi, dan alel AG dan GG yang rendah. Hal tersebut berbeda dengan bangsa lainnya disebabkan sapi bali termasuk bangsa Bos javanicus dan berbeda dengan bangsa sapi lainnya (Bos taurus dan sapi Pesisir). Perbedaan bangsa Bos javanicus dan bangsa sapi lainnya dikemukakan juga oleh Kusdiantoro et al. (2009) yang mengungkapkan hubungan maternal sapi bali asli dari empat wilayah berbeda (Sulawesi, Bali, Sumatera Selatan, dan Sumatera Barat) dengan banteng ditinjau dari analisis DNA mitokondria (mt), kromosom Y (Y) dan mikrosatelit alel autosom ( $\mu \mathrm{st})$, dan terpisah dari sapi lokal lainnya (sapi pesisir, aceh, dan madura) dan sapi-sapi zebu (Bos indicus). Tingginya frekuensi alel G pada Bos taurus (limousin dan simmental) dikemukakan juga oleh Di Stasio et al., (2005) yang mengidentifikasi frekuensi alel gen GHR $\mid A l u I$ pada sapi piedmontese yang memiliki frekuensi alel $\mathrm{G}$ lebih tinggi $(0,510)$ dibandingkan alel A $(0,490)$.

Frekuensi alel A fragmen gen GHR I AluI yang tinggi 0,988 dan frekuensi alel $G$ yang rendah $(0,012)$ pada sapi bali (Bos javanicus) menunjukkan bahwa fragmen gen GHRIAluI bersifat monomorfik. Falconer \& Mackay (1996) menyatakan bahwa sebuah lokus polimorfik ditandai dengan salah satu frekuensi alelnya kurang dari 0,99. Frekuensi alel A gen GHRIAluI sapi bali yang tinggi tersebut atau bersifat monomorfik memperjelas perbedaan sapi bali dengan dengan sapi bangsa lainnya, sehingga menjadi informasi penting dalam pengambilan keputusan pengembangan sapi bali sebagai ternak lokal utama penghasil daging ke depan.

Frekuensi alel dan genotipe gen $\mathrm{GHR} \mid A l u \mathrm{I}$ pada sapi bali yang menunjukkan monomorfik disebabkan sapi bali merupakan ternak domestik daerah tropis Indonesia. Sapi bali sebagai hasil domestikasi langsung dari banteng Bos banteng (Namikawa et al., 1980), telah beradaptasi dengan lingkungan tropis sehingga pengaruh lingkungan berperan terhadap sifat produksinya. Proses adaptasi tersebut merupakan proses evolusi dan seleksi pada spesies ternak domestik.

Kemampuan adaptasi sapi bali didapatkan dari seleksi alam dan berpengaruh terhadap sifat produksinya. Umumnya seleksi alam terpusat pada pembentukan individu-individu yang kuat dan tahan terhadap tantangan lingkungan alam sekitarnya. Hal tersebut mengakibatkan ternak hasil seleksi alam sifat produksinya (pertumbuhan) rendah disebabkan sifat yang diekspresikan terbatas hanya untuk mempertahankan hidupnya. Terkait kemampuan sapi Bali dalam mengekspresikan sifat yang dibutuhkan dalam bertahan hidup, sebuah fenomena variasi genetik pada individu berlaku. Fenomena kelenturan fenotipik sebagai hasil seleksi alam menyebabkan genotipe sapi bali cenderung kurang bervariasi (monomorfik). Noor (2002) menyatakan bahwa kemampuan suatu individu/genotipe untuk menampilkan lebih dari satu bentuk morfologi, status fisiologi dan/atau tingkah laku sebagai respon terhadap perubahan lingkungan disebut sebagai kelenturan fenotipik.

Hasil uji khi-kuadrat $\left(\chi^{2}\right)$ terhadap frekuensi genotipe gen GHR I AluI menunjukkan perbedaan antara rasio pengamatan dan rasio harapan atau terjadi keadaan ketidakseimbangan $\mathrm{H}-\mathrm{W}$ pada populasi sapi bali, limousin dan pesisir, sedangkan keseimbangan $\mathrm{H}-\mathrm{W}$ hanya terjadi pada populasi sapi simmental. Ketidakseimbangan $\mathrm{H}-\mathrm{W}$ pada populasi sapi bali dan pesisir diduga disebabkan oleh seleksi alam yang terjadi dalam proses domestikasi sapi bali dan proses pembentukan sapi pesisir. Seleksi negatif yang terjadi pada sapi bali dan pesisir yakni pemotongan dan penjualan sapi-sapi yang mempunyai pertumbuhan yang baik oleh peternak juga diduga menjadi penyebab ketidakseimbangan H-W. Jakaria et al. (2007) menyatakan bahwa pada populasi sapi pesisir di Kabupaten Pesisir Selatan menunjukkan frekuensi genotipe tidak seimbang $(\mathrm{P}<0,01)$ terhadap penciri PCR-RFLP $\mathrm{GH} \mid \mathrm{MspI}$ dan $\mathrm{GH} \mid A l u \mathrm{I}$. Hal ini berarti bahwa pada populasi sapi pesisir tidak terjadi kawin acak, adanya seleksi, mutasi, migrasi dan terjadi endogami.

Ketidakseimbangan $\mathrm{H}-\mathrm{W}$ pada sapi limousin terjadi disebabkan ukuran populasi sampel yang kecil. Hal ini sesuai dengan pendapat Falconer \& Mackay (1996) yang menyatakan bahwa ukuran populasi sampel juga mempengaruhi perubahan frekuensi genotipe dari generasi ke generasi. Menurut Vasconcellos et al. (2003), beberapa kejadian seperti akumulasi genotipe, populasi 
Tabel 2. Nilai heterozigositas pengamatan (Ho) dan heterozigositas harapan $(\mathrm{He})$ gen GHR I AluI pada sapi bali

\begin{tabular}{lccc}
\hline \multicolumn{1}{c}{ Bangsa sapi } & $\mathrm{n}$ & $\mathrm{H}_{\text {observed }}$ & $\mathrm{H}_{\text {expected }} \pm \mathrm{SE}$ \\
\hline Bali & 162 & 0,006 & $0,018 \pm 0,001$ \\
Limousin & 21 & 0,095 & $0,408 \pm 0,017$ \\
Simmental & 17 & 0,529 & $0,389 \pm 0,021$ \\
Pesisir & 48 & 0,021 & $0,474 \pm 0,007$ \\
\hline
\end{tabular}

Keterangan: $\mathrm{n}=$ jumlah individu.

yang terbagi, mutasi, seleksi, migrasi dan perkawinan dalam kelompok/populasi yang sama (endogami) dapat menimbulkan ketidakseimbangan dalam populasi.

Pendugaan nilai heterosigositas pengamatan $\left(H_{o}\right)$ dan heterozigositas harapan $\left(H_{e}\right)$ dihitung untuk mendapatkan keragaman genetik (genetic variability) dalam populasi yang dapat digunakan untuk membantu program seleksi pada ternak yang akan digunakan sebagai sumber genetik pada generasi berikutnya (Marson et al., 2005). Nilai heterozigositas pengamatan $\left(H_{0}\right)$ dan heterozigositas harapan $\left(H_{e}\right)$ gen GHRIAluI dinyatakan dalam Tabel 2. Sapi simmental memiliki nilai tertinggi $\left(H_{o}=0,529\right)\left(H_{e}=0,389 \pm 0,021\right)$ dan sapi bali memiliki nilai terendah $\left(H_{o}=0,006\right)\left(H_{e}=0,018 \pm 0,001\right)$.

Perbedaan antara nilai $H_{o}$ dan $H_{e}$ mengindikasikan bahwa telah terjadinya ketidakseimbangan $\mathrm{H}-\mathrm{W}$, yaitu perubahan frekuensi gen yang cukup besar dari satu generasi ke generasi lainnya disebabkan oleh adanya seleksi, migrasi, mutasi dan genetic drift (Falconer \& Mackay, 1996; Noor, 2008). Keragaman genetik yang kecil pada sapi bali disebabkan oleh kemampuan adaptasi yang didapatkan dari seleksi alam daerah tropis. Kemampuan hidup dalam kondisi yang terbatas (nutrisi dan iklim) memberikan dampak sapi bali mengekspresikan sifat yang sesuai dengan kebutuhannya dalam mempertahankan hidup. Kultur sel atau organisme secara keseluruhan memberikan respon dengan mensintesa sejumlah protein yang dikenal sebagai heat shock protein atau stres protein, pada saat yang bersamaan sebagian besar protein akan switched off (Noor, 2002).

Berdasarkan Tabel 3, nilai PIC yang diperoleh, penciri PCR-RFLP gen GHR I AluI pada sapi bali $(0,018)$ kurang informatif jika dibandingkan pada sapi limousin, simmental dan pesisir. Botstein et al. (1980) menyatakan bahwa kriteria nilai PIC termasuk ke dalam kelompok rendah jika nilai PIC $\geq 0,25$, nilai PIC sedang $0,25<$ PIC $<$ 0,5 dan nilai PIC tinggi jika $\geq 0,5$. Nilai PIC tidak hanya
Tabel 3. Pendugaan nilai polymorphic informative content (PIC) pada sapi bali

\begin{tabular}{lcc}
\hline \multicolumn{1}{c}{ Bangsa sapi } & $\mathrm{n}$ & PIC \\
\hline Bali & 162 & 0,018 \\
Limousin & 21 & 0,314 \\
Simmental & 17 & 0,270 \\
Pesisir & 48 & 0,466 \\
\hline
\end{tabular}

Keterangan: $n=$ jumlah individu.

dapat digunakan untuk menentukan informatifnya suatu penciri, akan tetapi juga dapat digunakan untuk menentukan ada tidaknya suatu alel polimorfik, selain didasarkan nilai heterozigositas (Botstein et al., 1980).

\section{Sekuen Gen GHR | AluI}

Hasil analisis homologi gen GHR menunjukkan bahwa gen GHR|AluI sapi bali, limousin, simmental, dan pesisir memiliki nilai kesamaan yang tinggi (98-99\%) terhadap sekuen gen bovine growth hormon receptor (bGHR) yang terdapat di GenBank (Kode Akses. EF207442). Mutasi ditemukan pada situs AluI basa A menjadi G pada posisi 81 pb (Gambar 4) gen GHR I AluI hasil amplifikasi atau 3338 pb sesuai sekuen GHR di GenBank (Kode Akses. EF207442).

Mutasi yang ditemukan pada gen GHR|AluI tersebut sesuai dengan mutasi yang ditemukan Ge et al. (2000); Di Stasio et al. (2005); Tatsuda et al. (2008); Han et al. (2009); dan Reandon et al. (2010), yakni perubahan basa A menjadi G, yang mengubah serina (AGC) menjadi glisina (GGC). Mutasi yang terjadi pada fragmen gen GHR I AluI adalah mutasi subsitusi tipe transisi, atau perubahan basa nukleotida (A menjadi G) (Gambar 10). Sebagaimana dinyatakan Windelspecht (2007), mutasi transisi terjadi karena adanya subsitusi antara satu basa purin (adenin dan guanin) dengan basa purin lainnya atau antara satu basa pirimidin (timin dan sitosin) dengan basa pirimidin lainnya. Mutasi atau perubahan basa nukleotida banyak digunakan sebagai dasar identifikasi keragaman genetik.

Hasil jarak genetik gen GHRIAluI sapi bali, limousin, simmental, dan pesisir (Tabel 4) dan dendogram pohon genetik (Gambar 5) memperlihatkan pengelompokan (cluster) yang terpisah antara sapi bali dengan sapi limousin, simmental, dan pesisir. Hasil tersebut memperlihatkan bahwa Bos javanicus (sapi bali) mem-

\begin{tabular}{|c|c|c|c|c|c|c|c|c|c|c|c|c|c|c|}
\hline Sapi_Bali(AA) & GA & $\mathrm{ATC}$ & $\mathrm{ACA}$ & $\mathrm{C}-\mathrm{G}$ & TAG & $\mathrm{AGC}$ & $\mathrm{CA}-$ & AGC & TTT & $\mathrm{AAC}$ & $\mathrm{CAG}$ & GAA & GAC & A \\
\hline Sapi_Bali (BB) & . & $\ldots$ & $\ldots$ &.- & $\ldots$ & $\ldots$ & $\ldots \mathrm{A}$ & $\overline{\mathrm{G} .}$ & . . & $\ldots$ & $\ldots$ & $\ldots$ & $\cdots$ & . \\
\hline Sapi_Limousin (AA) & . & $\ldots$ & $\cdots$ &.- & $\cdots$ & . . &.- & $\ldots$ & . & . . & . . & . . & . & . \\
\hline Sapi_Limousin (BB) & . & $\cdots$ & $\cdots$ & $\cdot-$ & $\cdots$ & $\cdots$ & . - & G. & $\cdots$ & $\cdots$ & $\cdots$ & $\cdots$ & $\cdots$ & - \\
\hline Sapi_Simmental (AB) & . & $\cdots$ & $\cdots$ &.- & $\cdots$ & &.- & G. . & $\cdots$ & $\cdots$ & $\cdots$ & $\cdots$ & $\cdots$ & . \\
\hline Sapi-Simmental (BB) & A. & $\ldots$ & $\ldots$ &.- . & .. & $\ldots$ & $\ldots-$ & G.. & $\ldots$ & $\ldots$ & $\ldots$ & $\ldots$ & $\ldots$ & . \\
\hline Sapi_Pesisir(AA) & . & $\cdots$ & $\cdots$ & . A. & $\cdots$ & $\cdots$ & $\ldots-$ & $\cdots$ & $\cdots$ & $\cdots$ & $\cdots$ & $\cdots$ & $\cdots$ & - \\
\hline Sapi-Pesisir(BB) & . & $\ldots$ & $\ldots$ &.- . & . & $\ldots$ & $\ldots A$ & G. . & $\ldots$ & $\cdots$ & $\ldots$ & $\ldots$ & $\ldots$ & . \\
\hline
\end{tabular}


Tabel 4. Jarak genetik berdasarkan gen GHR I AluI pada sapi bali

\begin{tabular}{lccccc}
\hline \multicolumn{1}{c}{ Bangsa sapi } & & 1 & 2 & 3 & 4 \\
\hline Bali & {$[1]$} & 0,000 & & & \\
Limousin & {$[2]$} & 0,497 & 0,000 & & \\
Simmental & {$[3]$} & 0,527 & 0,001 & 0,000 & \\
Pesisir & {$[4]$} & 0,142 & 0,108 & 0,122 & 0,000 \\
\hline
\end{tabular}

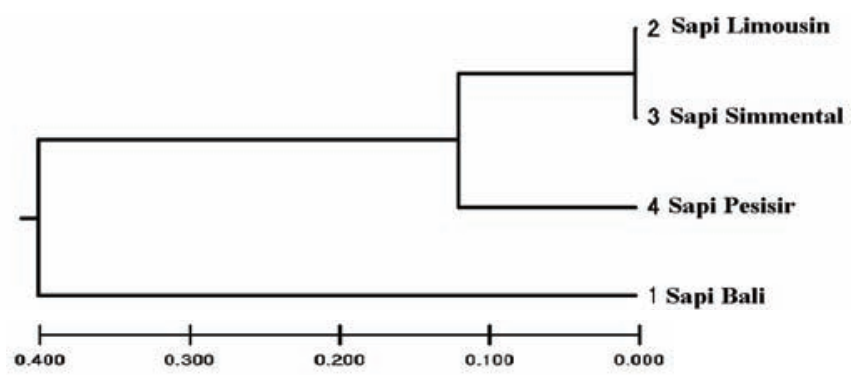

Gambar 5. Dendogram pohon genetik berdasarkan gen GHRI AluI pada sapi bali

punyai hubungan yang jauh terhadap sapi Bos taurus (limousin dan simmental) dan sapi lokal lainnya (sapi pesisir). Sapi bali sebagai sapi lokal asli yang merupakan domestikasi langsung dari banteng liar (Bos banteng) (Namikawa et al., 1980) dan merupakan hasil seleksi alam daerah tropis yang berbeda dengan bangsa sapi Bos taurus yang merupakan sapi daerah subtropis.

\section{KESIMPULAN}

Gen GHR I AluI pada sapi bali bersifat monomorfik dengan frekuensi alel A dan genotipe AA yang tinggi, sedangkan pada sapi limousin, simmental dan pesisir bersifat polimorfik. Nilai pendugaan heterozigositas dan PIC gen GHRIAluI pada sapi bali rendah disebabkan tingkat keragamannya yang rendah jika dibandingkan dengan sapi limousin, simmental, dan pesisir. Hasil sekuen gen GHRIAluI menunjukkan adanya mutasi basa adenin (A) menjadi guanin (G) pada posisi $81 \mathrm{pb}$ (3338 pb Kode Akses. EF207442 GenBank). Berdasarkan pohon genetik gen GHR IAluI terdapat pemisahan yang jelas antara sapi bali, limousin, simmental, dan pesisir.

\section{DAFTAR PUSTAKA}

Andreas, E. 2010. Telaah kualitas daging serta identifikasi keragaman gen GH dan GHR pada kerbau. Tesis. Program Pascasarjana, Institut Pertanian Bogor, Bogor.

Beauchemin, V. R., M. G. Thomas., D. E. Franke, \& G. A. Silver. 2006. Evaluation of DNA polymorphisms involving growth hormone relative to growth and carcass characteristics in Brahman steers. Genet. Mol. Res. 5:438-447.

Bugiwati, S. R. A. 2007. Pertumbuhan dimensi tubuh pedet jantan sapi bali di Kabupaten Bone dan Barru Sulawesi Selatan. J. Sains dan Tekno. 7:103-108.

Botstein, D. R., L. White., M. Skolnik, \& R. W. Davis. 1980. Construction of a genetic linkage map in man using restriction fragment length polymorphisms. Am. J. Hum. Genet. 32:314.
Di Stasio, L., G. Destefanis., A. Brugiapaglia., A. Albera, \& A. Rolando. 2005. Polymorphism of the GHR gene in cattle and relationships with meat production and quality. Anim. Genet. 36:138-140.

Direktorat Jenderal Peternakan. 2009. Buku Statistik Peternakan Tahun 2008. Departemen Pertanian, Jakarta.

Falconer, D. S \& T. F. C. Mackay. 1996. Introduction to Quantitative Genetics. $4^{\text {th }}$. Ed. Longman Inc, New York.

Ge, W., M. E. Davis., H. C. Hines, \& K. M. Irvin. 2000. Rapid communication: Single nucleotide polymorphisms detected in exon 10 of the bovine growth hormone receptor gene. J. Anim. Sci. 78:2229-2230.

Hale, C.S., W. O. Herring, H. Shibuya, M. C. Lucy, D. B. Lubahn, D. H. Keisler, \& G. S. Johnson. 2000. Decreased growth in Angus steers with a short TG-microsatellite allele in the P1 promoter of growth hormone receptor gene. J. Anim. Sci. 78:2099-2104.

Han, S. H., I. C. Cho, J. H. Kim, M. S. Ko, H. Y. Jeong, H. S. Oh, \& S. S. Lee. 2009. A GHR polymorphism and its associations with carcass traits in Hanwoo cattle. Genes \& Genom. 31:35-41.

Handiwirawan, E. \& Subandriyo. 2004. Potensi dan keragaman sumberdaya genetik sapi Bali. Wartazoa 14:3.

Jakaria, D. Duryadi, R. R. Noor, B. Tappa, \& H. Martojo. 2007. Evaluasi keragaman genetik gen hormon pertumbuhan sapi Pesisir Sumatera Barat menggunakan penciri PCRRFLP. Med. Pet. 30:1-10.

Kaps, M. \& W. R. Lamberson. 2004. Biostatistics for Animal Science. CABI Publishing, London.

Kusdiantoro, M., M. Olsson, H. T. A. van Tol, S. Mikko, B. H. Vlamings, G. Andersson, H. RodrIguez-MartInez, B. Purwantara, R. W. Paling, B. Colenbrander, \& J. A. Lenstra. 2009. On the origin of Indonesian cattle. Plos one 4:e5490.

Lin, B. Z, S. Sasazaki, J. H. Lee, \& H. Mannen. 2009. Genetic diversity of growth hormone receptor gene in cattle. J. Anim. Sci.. 80:528-531

Marson, E. P., J. B. S. Ferraz, F. V. Meirelles, J. C. C. Balieiro, J. P. Eler, L. G. G. Figuerido, \& G. B. Mourao. 2005. Genetic characterization of European-Zebu composite bovine using RFLP markers. Genet. Mol. Res. 4:496-505.

McGinnis, S. \& T. L. Madden. 2004. BLAST: at the core of a powerful and diverse set of sequence analysis tools Nucleic Acids Research. 32:20-25.

Namikawa, T., J. Otsuka, \& H. Martojo. 1980. Coat colour variations of Indonesian cattle. The origin and phylogeny of Indonesian native livestock (Part III): Morphological and genetically investigations on the interrelationship between domestic animals and their wild forms in Indonesia. The Research Group of Overseas Scientific Survey 31-34. p. 19-27.

Nei, M. \& S. Kumar. 2000. Molecular Evolution And Phylogenetics. Oxford University press, New York.

Noor, R. R, A. Farajallah, \& M. Karmita. 2001. Pengujian kemurnian sapi bali dengan analisis hemoglobin dengan metode isoelectric focusing. Hayati 8:107-111.

Noor, R. R. 2002. Genetika Ekologi. Laboratorium Pemuliaan dan Genetika Ternak. Fakultas Peternakan, IPB.

Noor, R. R. 2008. Genetika Ternak. Penebar Swadaya, Jakarta.

Reardon, W., A. M. Mullen, T. Sweeney, \& R. M. Hamill. 2010. Association of polymorphisms in candidate genes with colour, water-holding capacity, and composition traits in bovine M. longissimus and M. semimembranosus. Meat Sci. (In Press).

Tatsuda, K., A. Oka, E. Iwamoto, Y. Kuroda, H. Takeshita, H. Kataoka, \& S. Kouno. 2008. Relationship of the bovine growth hormone gene to carcass traits in Japanese black cattle. J. of Anim. Breed. and Genet. 125:45-49. 
Vasconcellos, L. P. M. K., D. T. Talhari, A. P. Pereira, L. L. Coutinho, \& L. C. A. Regitano. 2003. Genetic characterization of Aberdeen Angus cattle using molecular markers. Genet. Mol. Bio. 26:133-137.

Weir, B. S. 1996. Genetic Data Analysis : Method for Discrete Population Genetic Data. Second ed. Sinauer Associates. Sunderland, MA USA.
Windelspecht, M. 2007. Genetics 101. Greenwood Press, London

Zhou, Y \& H. Jiang. 2005. Trait-associated sequence variation in the bovine growth hormone receptor 1A promoter does not affect promoter activity in vitro. Anim. Genet. 36:156-159. 